\title{
Into the eye of the storm
}

\author{
As Hurricane Rita headed for the \\ US coast, Mark Schrope scored a \\ rare trip into the gathering winds.
}

It's the up and down drafts that are the problem, I quickly learned while flying into Hurricane Rita. Crosswinds, even as fast as 250 kilometres per hour, aren't a big deal to a military P-3 airplane travelling 400 kilometres per hour. But a few of the convective drafts could have easily knocked me out of my seat if I hadn't been wearing a four-point safety belt. During one particularly turbulent moment, my free arm involuntarily flew as high as my head, giving some indication of what my internal organs were dealing with.

Throughout the hurricane season, the National Oceanic and Atmospheric Administration runs these stomach-churning reconnaissance flights from MacDill Air Force Base in Tampa, Florida. On 23 September, I was on a flight bound for Rita, just hours before the storm hit the Texas and Louisiana coast.

Such flights are the only way researchers can accurately gather key parameters on a hurri-

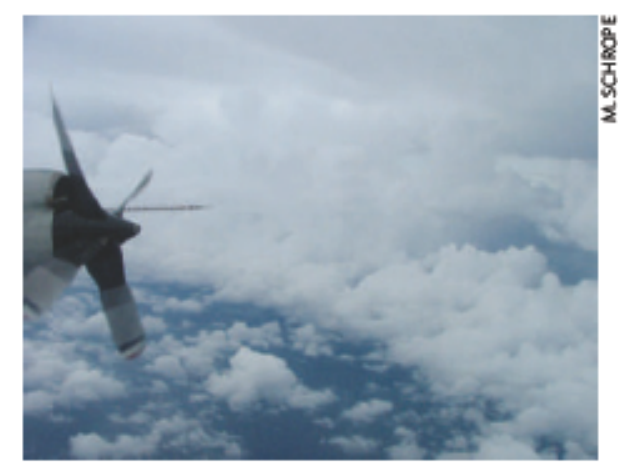

Angry sky: the outer rainbands of Hurricane Rita seenfrom a plane approaching the storm.

cane, such as its central pressure and wind speeds. The pilots, experienced at flying into storms most others would consider deadly, use radar to thread a path through the outer bands and to target the central eye.

We made our first pass through the infamous eyewall, typically the most powerful part of a storm, just southwest of New Orleans. What followed was mostly a complete whiteout, but after a couple of minutes of turbulence we broke out into the eye. The day before, I was told, Rita had had a classic stadium-shaped eye, with clearly defined walls surrounding an open centre. Now, as the storm was weakening substantially from its former category- 5 fury, the eye was poorly defined and filled with thin clouds. Quantifying this dramatic drop in strength was one of the flight's key discoveries. We were glad to give up the better show in exchange for a weaker landfall.

The eyewall passes caused the greatest flurry of activity on the plane. A technician across the aisle from me loaded data-gathering instruments called dropsondes into tubes and dropped them out of the plane, one by one.

Our departure from the eye after the first pass was much more jolting than the entry had been, as the western wall was more intense. It was on these turbulent passes that I came closest to 'earning my patch', as experienced fliers say. All passengers on the hurricane flights receive a commemorative patch, but veterans say you need a pounding to truly earn it.

Yet we knew our choppy flight was much smoother than what the residents of Texas and Louisiana, many of whose homes Rita would flood, would soon experience. While airborne, we heard a report that winds in Louisiana had already reached 60 kilometres per hour. Knowing firsthand what was to come, one crew member said respectfully: "Just wait."

\section{School board in court over bid to teach intelligent design}

\section{HARRISBURG, PENNSYLVANIA}

AUS federal court this week began hearings on whether intelligent design deserves an airing in high schools as a viable scientific theory. The idea, which suggests that an intelligentcreator shaped the course of evolution, is seen by many as an attempt to sneak creationism into the classroom.

On 26 September, scientists, legal experts, reporters and local families crowdedinto a ninth-floor courtroom in Harrisburg, Pennsylvania, to hear the opening arguments in the case. At issue is whe ther a school district in the nearby town of Dover has the right to require that intelligent design be mentionedin science classes.

The trial, observerssay, is the most public airing todate on whether intelligent design should be taught in schools, and its outcome is likely to have ramifications for the teaching of science nationwide.

"This case is probably the most important legal situation for creation and evolution in the past 18 years," Eugenie Scott, director of the National Center for Science Education in Oakland, California, said last week.

LastNovember, Dover'sschool board ordered that a short statement be read at the beginning of biology classes, which pointed to "gaps" in Darwin's theory of evolution and endorsed intelligent design as an alternative. Eleven parents filed suit against the district, claiming that the statement violated the required separation of church and state in lessons.

Eric Roths child, a Philadelphiaarea lawyer representing the parents, hammered home the point in opening arguments before Judge John Jones, who will adjudicate the suit "The boardchanged the scientific curriculum to support a specific religious viewpoint," Rothschild told the judge. "And in doing so they ignored the body of scientific knowledge."

But Pennsylvania standards require schools to teachstudents to think critically about scientific theories, and that's what the board's four-paragraphstatement is designed todo, said Patrick Gillen of the Christian-oriented Thomas More Law Center in Ann Arbor, Michigan, who is representing the board. "This case is about free enquiry ineducation, not a religious agenda," Gillen said.

The plaintiffs' first witness was biologist Kenneth Miller of Brown University in Providence, Rhode Island, author of the biology textbook used in Dover classrooms. In more than three hours of testimony, Miller explained the scientific concepts of evolution and sought to show how they could explain things that intelligentdesign advocates claimed were evidence of an intelligent creator.
"I believe thatintelligent design is inherently religious," Miller told the judge. "AndI think that the statement by the Dover board of education falsely undermines the scientific state of evolution theory."

During cross-examination, defence lawyers questioned Miller aggressively about the completeness of evolution theory. "The origin of DNA and RNA and their evolution is an unansweredquestion, is that correct?" asked Robert Muise, also of the Thomas More Law Center. Miller responded that some aspects of early DNA and RNA had been replicated, but that many questions remainedunanswered "Iwould rather say that Darwin was incomplete, not that Darwin was inadequate," he told the court.

The plaintiffs' testimony is likely to continue for at least a week before the defence takes over. A ruling is not expected until November. Geoff Brumfiel 